\title{
HARMFULNESS OF GIANT HERACLEUM HOGWEED AND METHODS OF THEIR CONTROL
}

Goal. Analysis and generalization of domestic and foreign experience on the invasion and harmfulness of giant hogweeds, including Sosnowski's heracleum Sosnowskyi Mandenova to disseminate scientifically sound information on practical methods of control and prevention of further spread of giant hogweed, promoting biological conservation. Methods. Systemanalytical, abstract-logical, empirical. Results. According to research, scientists have predicted that the penetration of alien species into new territories is constant. However, more and more these processes are intensified under the influence of human activity. One of the indisputable facts of recent centuries is that man is increasing not only his numbers but also his needs. To meet them, she persistently seeks to expand the range of processed food, medicinal and ornamental plants. A clear example of this is the situation with giant hogweed. Imported into Western Europe in the XIX century as an ornamental plant Borage Mantegazzi today poses a real threat to the ecosystems of almost all countries of the European continent. The seeds of the London population of Persian borage were sown in 1836 by English gardeners in northern Norway, from where it quickly spread throughout the Scandinavian countries. In the former USSR in the postwar years, Sosnowski's hogweed was actively studied and implemented, which has now become widespread in the natural ecosystems of the CIS countries and Ukraine in particular. Conclusions. According to research, scientists have predicted that giant hogweed poses a great danger and threatens the natural ecosystems of our country and the West, control of Mantegazzi hogweed will be much more difficult and costly than with Sosnowski hogweed. For this reason, it is essential to take preventive measures to locate and remove plants of very dangerous invasive species and other species with a polycarpic cycle of de-

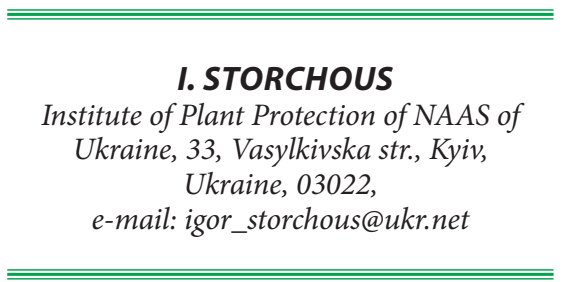

velopment, as well as to prevent their widespread spread.

giant hogweed; Sosnowski's hogweed; invasive species; harmfulness; control methods

The active spread of giant hogweeds as invasive species began around the mid - 1980's, and almost simultaneously in different parts of Ukraine, Europe, Russia, and the Baltic countries. This necessitated the study of biology, ecology and other features of plant growth and development. Particularly acute problem of giant borage adds to the fact that they contain photodynamically active compounds - photosensitizers, which when exposed to plant sap on exposed parts of the body and subsequent irradiation of these parts with sunlight, can cause skin inflammation or dermatitis, which have signs of first burns. second and even third degree. Once in new territories, alien species often find favorable conditions for mass reproduction. This is facilitated by the absence in the new conditions of pests and diseases that could limit their numbers.

The genus Borschivnik, Heracleum, has about 70 species. Within the former USSR, 39 species were distributed in the wild, most of them in the Caucasus. Some species of hogweed are able to form a huge biomass (up to $100 \mathrm{t} / \mathrm{ha}$ or more). Heracleum is one of the large genera of the Apiaceae family. A relic of Tertiary forest vegetation, one of the primitive taxa of this family. The name Heracleum is given to the plant by Pliny [1].
In the 60's and 70's, large-scale experiments were carried out on the introduction of hogweed into production as fodder and leachate crops. According to the results of research and extensive production tests, Sosnowski's hogweed was recommended for introduction as a fodder silage crop. Despite the efforts, the cultivation of Sosnowski's hogweed on a production scale did not become widespread. Work with him was stopped, but the «newcomer» was stable. From research sites and agricultural fields, it began to penetrate and spread in natural plant communities. In the absence of isolation, hogweeds easily interbreed, forming spontaneous hybrids, which further prevents the definition of the species $[1,2]$.

Adventive species have a negative effect on local vegetation [3], and their aggressiveness towards local plant species, enhanced by morphological differentiation and the presence of intermediate forms, etc., is given to the complete displacement of some of them. Due to such aggres-

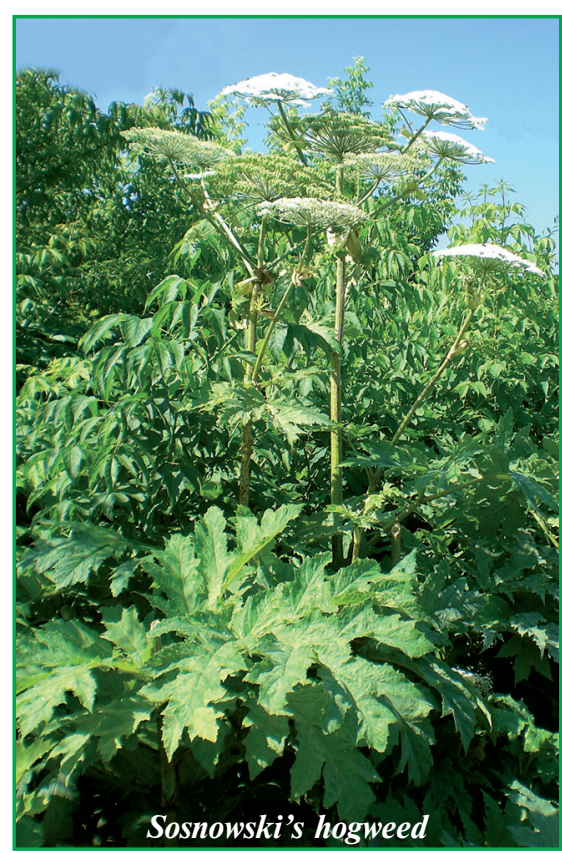


sive properties during the introduction, significant irreversible processes in the environment can sometimes occur at the genetic, species and ecosystem levels [4].

The active spread of adventitious species is facilitated by high plowed areas, the appearance of abandoned plots, gardens, neglect of control measures and destruction of giant hogweeds on fallow lands, along field roads, roadside lanes, under power line pylons, in landfills, etc. Under such conditions, the expansion of foreign plants increases and they become vicious field weeds with a high level of harmfulness, which can lead to significant crop losses and economic losses [5-9].

Giant hogweeds, being an invasive alien species, due to favorable conditions, have spread especially actively and aggressively on the territory of Ukraine and pose a danger to the local flora and agricultural lands. Scientists believe that one of the most dangerous are Heracleum Mantegazzianum Sommier \& Levier and Heracleum Sosnowskyi Mandenova. Sosnowski's hogweed was imported into the country as a silage crop, and Mantegazzi hogweed as an ornamental crop that now grows in the Carpathians [10-13].

In Ukraine, there is no reliable information on the composition and distribution ratio of giant hogweed in natural populations, and therefore this is a special problem and needs to be thoroughly studied in order to prevent the spread and capture of new territories.

Goal - of the genus Heracleum; their distribution; identification; harmfulness; biology and ecology, impact on flora and human health, methods of control of giant hogweed.

Methods - system-analytical, abstract-logical, empirical.

Results and discussion. It is established that the penetration of alien species into new territories is constant. The active spread of giant hogweeds as invasive species began around the mid - 1980's, almost simultaneously in different parts of Ukraine, Europe, Russia and the Baltic countries. This has led to the need to study the harmfulness, features of biology and ecology, the impact on the aboriginal flora and human health, the development of methods to control giant hogweed.

Due to the rapid development of populations, giant hogweeds displace other plants and maintain a dominant position in the occupied territories. The spread of plants in Western and Northern Europe was due to human influence, interest in his unusual appearance. The seeds were carefully sent and sown in botanical gardens and estates. This trend lasted until the end of the XIX century. Then such cultivation became less, and it stopped completely after the appearance in Western European literature, around 1900, of warnings about the dangers posed by borage plants.

More than 20 different species of the genus Heracleum are known in Europe. Three species: Heracleum mantegazzianum Sommier \& Levier, Heracleum sosnowskyi Mandenova and Heracleum persicum Desfontaines form a group of giant borage.

The range of the genus Heracleum covers a wide range of Eurasia and North America. In Eurasia, the northern boundary of the genus extends from the Scandinavian Peninsula to Kamchatka, and in North America - from Alaska to Labrador and Newfoundland, the southern border covers North Africa, Central and Eastern Asia, in North America stretches from California to California and southern California. Against the background of this large area of distribution are clearly several large centers: East Asia, the mountainous regions of Southern Europe and the Caucasus. The natural range of $H$. mantegazzianum is the Western Caucasus, H. Sosnowskyi - Central and Eastern Caucasus [1, 14], Transcaucasia and Turkey, while $H$. persicum is distributed in Turkey, Iran and Iraq.

H. mantegazzianum - the most famous of the giant hogweed, was described as a new species for science in 1895 . Today, of the 19 countries in which it grows, in fourteen H. mantegazzianum appeared before 1900, in two more first mentioned. between 1900 and 1960 and only in three countries - after 1960 [8, 15, 16].

$H$. Sosnowskyi was first described in 1944 and began to be used in Europe as a crop due to the high yield, which provided a supply of silage for livestock. Because the plant is hardy and cold-tolerant, it has become widespread in northwestern Russia, where cultivation first began in 1947. Since the 1940 's, it has been sown in Latvia, Estonia, Lithuania, Belarus, Ukraine, and the former German Democratic Union. Repub- lic, since 1958 - in Poland. The giant hogweed, which originates from the Caucasus Mountains, from the region between the Black and Caspian Seas, reached the United States in the early 20th century. Currently, the Baltic countries no longer practice the cultivation of $H$. Sosnowskyi. In the northern regions of Russia it is still grown in some places. Sosnowski's hogweed has spread significantly during its cultivation, in particular in Eastern Europe - Germany, Belarus, the Baltic States, Poland, Russia and Ukraine [18, 19, 20].

The history of $H$. persicum in Europe is less known, it was described earlier than others (in 1829) and often $H$. persicum plants after their detailed study belonged to $H$. mantegazzianum or $H$. Sosnowskyi. For as yet unknown reasons, despite being grown in many botanical gardens in Europe, $H$. persicum has not become widespread [14-16]. The only reliable naturalized population of this species is found in Scandinavia, where it is also known as the «palm tree from Tromso» or Heracleum «laciniatum».

The European and Mediterranean Plant Quarantine and Protection Organization (EPPO) of Mantegazzi, Sosnowski and Persian borage are included in the List of Invasive Alien Plants. A national standard for regulating the distribution and eradication of giant hogweeds has been developed for these species [17, 21].

Studies of species characteristics for accurate identification have shown that the most important distinguishing feature of invasive giant hogweed H. mantegazzianum, H. Sosnowskyi, $H$. persicum is their size. The height of the plants reaches $4-5 \mathrm{~m}$. The diameter of the stem is usually $5-10 \mathrm{~cm}$ (in $H$. persicum smaller).

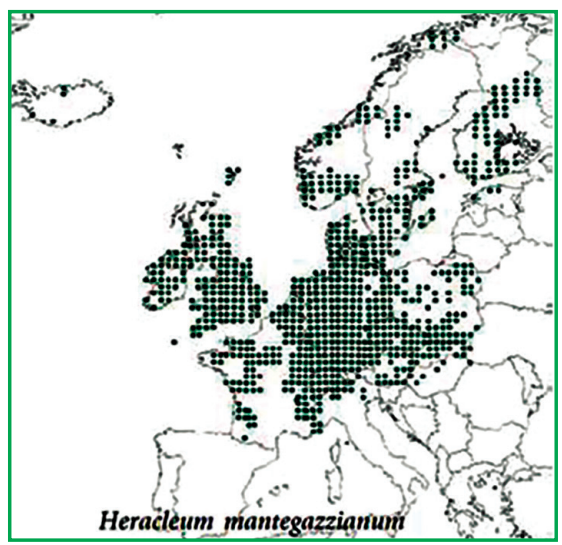

Distribution of Mantegazzi hogweed in Europe [15] 
The leaves are up to $3 \mathrm{~m}$ long Inflorescence in the form of an umbrella (up to $80 \mathrm{~cm}$ ) consists of clusters of white or pink flowers. Each inflorescence has from 30 to 150 flowers. One plant can have more than 80 thousand flowers. Flowering period is June-August. H. mantegazzianum and $H$. Sosnowskyi monocarpic (ie they complete the life cycle after flowering), while $H$. persicum - polycarpic. All giant hogweed contains phototoxic juice [14, 22-24].

H. mantegazzianum is endemic to the Caucasus. Mantegazzi's hogweed was brought to Ukraine, namely to the territory of the present-day Ivano-Frankivsk region, from Karlovy Vary in 1927 [11].

Heracleum sibiricum L., Heracleum sphondylium L., Heracleum Lehmannianum Bunge. much smaller than giant borage, usually 60-200 $\mathrm{cm}$ tall. The leaves are broad, no more than $60 \mathrm{~cm}$ long, with coarse veins and strongly hairy.

Siberian hogweed $H$. sibiricum in Belarus grows in deciduous forests, on edges, in bushes, meadows, meadows, wastelands, roadsides, ditches, etc. Occurs throughout the territory, often [25]. The life cycle of Siberian hogweed is up to 25 years.

Hogweed $H$. sphondylium has stiff hairs on the stem and leaves, usually grows to a height of 50 to $120 \mathrm{~cm}$, but individual specimens can reach a height of $2 \mathrm{~m}$. It blooms from June to August-October, depending on seasonal conditions.

Lehman's hogweed H. Lehmannianum grows on river banks, in humid places of the subalpine zone, sometimes forming thickets in the middle and high mountain belts. Flowering stem up to $2 \mathrm{~m}$ tall. Currently, this hogweed is widespread in Belarus [25].

In order not to harm the aboriginal (local) species, which look like giant hogweed, it is important to be able to distinguish them. At the beginning of the year, when the leaves of the plants have not yet fully opened, it is not easy even for experienced professionals. Some species of umbrellas are often mistaken for giant borage.

Such species include, for example, wild parsnip (Pastinaca sativa L.), which can be easily distinguished by its yellow color and pinnate leaves, which are divided into more than three parts and form rows around the central trunk. The plant often grows on roadsides, in meadows. Its juice can cause skin burns [26].

Angelica (Angelica archangelica L.) can also be mistaken for borage. This is a common garden plant that is grown to obtain aromatic stems and oils from seeds and rhizomes. The plant is $100-230 \mathrm{~cm}$ tall, inflorescences are rounded and consist of green flowers. Fruits ovoid, shaped without noticeable oily streaks. It often grows on river banks and in the wastelands of northern and eastern Europe. The juice of the plant is also harmful to the skin.

Wild angelica (Angelica sylvestris L.) is very similar to garden angelica. Both wild and garden are often confused with giant borscht because of their large size (over $2 \mathrm{~m}$ tall), purple stems and large inflorescences. Wild angelica has no hairiness and has a characteristic purple border at the base of the leaf. Distributed throughout Europe, especially in humid places [26].

An important place in research was given to the study of the harmfulness of giant hogweed. Sosnowski's hogweed H. Sosnowskyi, successfully acclimatized due to its extremely high reproductive capacity (the bulk of hogweed seeds crumbles directly near the mother plant and carried by wind, water flows, road and rail transport over long distances) and adaptability to local [22, 25, 27]. At the beginning of its expansion, borage plants grew on the roadsides, on the outskirts of settlements, wastelands, dumps, near farms, in ravines [28]. Over time, hogweed significantly increased the area of capture, and some of them merged into solid large thickets. Currently, hogweed is a vegetation of natural ecotopes, littering arable land and forests. According to the simulation results, it is predicted that borage populations will spread especially dynamically in the valleys along the rivers, as well as will represent a significant degree of anthropic impact in settlements and along transport links. According to the climatic model of $\mathrm{M}$. Simpson and others (2011), it is predicted that the populations of Sosnowski's hogweed will reach the upper forest belt, spreading over large areas. Penetrating into the upper forest and subalpine meadows, populations of this species will have a threatening impact on natural meadow vegetation, as well as on the succession of natural complexes. In general, based on the obtained models, the scientist states that all coastal settlements of the Ukrainian Carpathians in 2100 will be within a high risk of exposure to invasive processes due to the penetration of hogweed into the territory [18, 29, 30].

Sosnowski's hogweed was first identified as a harmful and dangerous weed in the Baltic States in the 1980 's. In 1986, in Latvia and in 1987 in Estonia, it was recognized as a dangerous weed, primarily due to the negative impact on the taste of meat and milk of animals that consumed it, and partly due to the risks to human and animal health. In Latvia in 2013, its area was 10.640 hectares, although this is only $2 / 3$ of the actual area of distribution of this species [32, 33]. In Estonia, in 2010, more than 1.300 hectares were covered by more than a thousand $H$. Sosnowskyi colonies, and there are probably also unknown colonies [34].

Based on the results of Sosnowski's research, it has been established that the number of distribution sites of this plant in Belarus increases by an average of $30 \%$ each year, and the area of existing populations - by $20-25 \%$. According to the analysis of the distribution of vegetation sites of Sosnowski's hogweed by land categories, it was found that almost half $(49 \%)$ of the population of this species is concentrated in land of industry, transport, communications, energy, defense and other purposes, primarily roadsides. A significant part of the population was found on agricultural lands $(23 \%)$ and lands of settlements, horticultural societies, country cooperatives $(26 \%)$, etc. $[28,35]$.

In the conditions of Ukraine, Sosnowski's hogweed continues to gradually occupy large territories. It grows especially densely on abandoned lands and in other places that are not used. Borschivnik forms monodominant thickets of different density with an area from several square meters to several hectares. Such thickets can occupy entire meadows or stretch in narrow strips, in particular along watercourses [36, 37].

The danger of hogweed has several aspects. If they form dense thickets, aboriginal species in them can not compete and disappear. Sosnowski's borage is able to reduce the size of populations of a large number of natural species in a short period of time, especially natural species in 
meadows and near reservoirs, up to their complete displacement due to their size, biomass accumulation rate and high plasticity [38]. Only 15-20 mostly weed-ruderal species of herbaceous plants are able to survive in the sinus with Sosnowski's hogweed $[27,39,40]$. From the structure of floodplain phytocenoses, this species displaces species of forage and medicinal plants. As a result - the disappearance with the grass of rhizomatous, rhizomatous plants, the place of which is occupied by borage. The root system of hogweed is rodshaped and does not form a dense turf and, accordingly, does not retain the soil layer, which leads to soil erosion [41].

Sosnowski's hogweed has been purposefully grown for almost 40 years. Thus, there were enough sources for the formation and spread of the invasive species. The main reasons that contributed to the expansion of Sosnowski's hogweed were the cessation of regular mowing in the fields where it was grown as animal feed, the cessation of targeted control in the fields after the collapse of collective and state farms, which were not cultivated for several years, and so on. Invasiveness of hogweed is due to a number of bioecological features: the formation of a large number of viable seeds, rapid growth and development, long flowering, the ability to self-pollinate, various methods of distribution [17, 42].

Human activity contributes to the spread of giant hogweed. Sosnowski's borschivnik from transformed habitats, from roadsides, canals and other ecotopes of ruderal character, spreads in natural, where it occupies stable niches and acquires high phytocenotic activity, acquires dominance or co-dominance [43]. European scientists have found that Sosnowski's hogweed increased the occupied area by $10 \%$ every year, although there was information about its more intensive distribution.

It is important to note that the active expansion is exacerbated by the fact that evolutionary changes are taking place in the populations of Sosnowski's hogweed. Scientists have carried out research at the molecular level of species from Ukraine, the Caucasus, Russia (Moscow region) and European countries. As a result of these studies, the genetic diversity of hogweed, which grows within its historically formed natural distribu- tion and secondary (anthropogenic) range, has been revealed. At the molecular level, genetic diversity has also been identified among hogweeds growing within a single geographical area, as well as polymorphism. It is possible that changes in DNA levels occurred under the influence of harmful aggressive substances, which are released in large quantities into the atmosphere from stationary sources of pollution, as well as on roadsides due to the negative impact of vehicle emissions, etc. [44, 45].

Control of hogweed requires the use of a wide arsenal of various methods and techniques. It is necessary to strengthen phytosanitary control over the condition of roads and railways, settlements, green areas, roadside and protective plantations. When choosing the best methods should take into account the ecological and coenotic features of species, as well as the peculiarities of economic activity of each region separately. The choice of method depends on the size of the area occupied by the plant, the density of its growth and access to the vegetation $[46,47]$.

The main biological features of giant hogweed are that they do not reproduce vegetatively. They usually bloom in the third or fifth year and their life cycle after seed production ends. In the absence of favorable conditions for flowering (due to lack of nutrients, shading, drought or regular mowing), the flowering process is delayed. In such cases, the plants can remain viable for up to 12 years. A clear understanding of the mechanism of reproduction is the key to successful control of invasive weeds [15].

The flowers are pollinated by insects, dioecious. Usually the appearance of seeds is the result of crosspollination, but self-fertilization is also possible. In the latter case, the seeds are also viable, more than half of them will germinate and give normal seedlings. Thus, one isolated plant can be the source of an entire weed population [48, 49].

In Central Europe, the plants bloom from mid-June to late July, and the seeds ripen in late August October. On average, one plant forms about 20 thousand seeds, but individual specimens form more than 100 thousand seeds. Although some of these seeds do not germinate, the ability to reproduce in this species is very high $[25,49]$.
Falling from the inflorescences, the seeds are in the soil and ripen in a short period of time. Most of the seeds $(95 \%)$ are in the upper $(5 \mathrm{~cm})$ layer of soil. By autumn, up to 12.000 seeds per $1 \mathrm{~m}^{2}$ of dense hogweed thickets, and by spring there are on average about 2.000 viable seeds, most of which are ready for germination, as they have already emerged from the winter dormancy.

Seeds of plants of many species can be stored in the soil for a long time without loss of viability. Such seeds are called «seed bank» $[15,49]$. It allows plants to germinate under optimal conditions and provide potential weediness. Freed from the inflorescence, the seeds of giant borage have an underdeveloped embryo, almost all of it is dormant and does not germinate in autumn. Germination is preceded by a period of embryo growth and recovery. Two months with an average daily temperature of $2-4^{\circ} \mathrm{C}$ is a sufficient period of time for the seeds to come out of dormancy.

In the spring, the "seed bank» of giant hogweed is significantly reduced (due to seed germination) and by summer has about 200 live seeds per $1 \mathrm{~m}^{2}$. These seeds are dormant, scientists estimate that about $8 \%$ are stored until next year, about $5 \%$ of the seeds are stored for two years. The fact that at least a small number of seeds can be stored for more than a year must be taken into account, taking into account the expansive nature of the reproduction of giant hogweeds, in order to control their distribution and reproduction [14, 15, 49].

Biological and ecological characteristics of invasiveness can be described as follows:

- germination in early spring before the appearance of other vegetation;

- relatively low death of young plants;

- rapid growth, the ability to grow in clusters and displace other (aboriginal) plants;

- the presence of a constant percentage of plants that bloom and provide seed formation;

- the ability of plants to suspend flowering under adverse conditions (until favorable conditions occur);

- early flowering, which allows the seeds to fully mature;

- ability to self-pollinate, the re- 
sult of which is a full-fledged seed,

- high fertility, which provides one plant the beginning of expansion;

- a large number of seeds in the «seed pot», as well as seeds that do not lose germination for more than one year,

- a very high percentage of seeds that germinate regardless of where the seeds have matured;

- rapid propagation of seeds by water and wind.

Due to these characteristics, as well as human activity, which accelerates the spread of seeds, giant borage is capable of rapid expansion.

The seeds of giant borage are usually in close proximity to the mother plant. In some cases, when the plant height is more than $2 \mathrm{~m}$, $60-90 \%$ of the seeds fall to the ground within a radius of $4 \mathrm{~m}$. The farther from the mother plant, the smaller the number of seeds, but individual seeds can spread over long distances and thus capture new territories [15].

Once in the vegetation, the seeds promote expansion, both at the local and regional levels. For example, in the Czech Republic, where the average seed spread is about $10 \mathrm{~m}$ per year, the area occupied by giant hogweeds increases by $1,200 \mathrm{~m}^{2}$ annually. At the regional level, the territory occupied by them has doubled in 14 years $[22,25,27,39,40,42]$.

During the research, the negative impact of giant borage on the aboriginal flora was established. Giant hogweeds grow especially densely in abandoned fields and other places acceptable for ruderal (weed) plants [15]. They can form plantations of different densities ranging from a few square meters to several hectares. These plantations can occupy entire meadows or stretch in narrow strips along rivers. Density varies from $1-3$ adult plants per $10 \mathrm{~m}^{2}$ to 20 plants per $1 \mathrm{~m}^{2}$. In places where many giant hogweeds are concentrated, about $80 \%$ of the light is absorbed by them, and other plants become noticeably suppressed. In Europe, where giant borage grows, the number and composition of other plant species have become smaller and the density of their growth has decreased $[15,21$, 25, 48, 49].

Borage is a danger to human health. The plant secretes a clear aqueous juice, which contains pho- tosensitizing compounds furanocoumarin (furocoumarin). These compounds cause burns when in contact with human skin and under the influence of ultraviolet radiation. The content of furanocoumarins in different parts of the plant is different. The phototoxic reaction is activated under the action of ultraviolet light after 15 minutes, and the sensitivity of the skin is manifested in 30-120 minutes after contact with the plant. Also, some furanocoumarins are carcinogenic (can cause cancer) and teratogenic (cause indulgence) [49, $50,51]$.

After 24 hours, the skin turns red (erythema), a large amount of fluid accumulates under the skin at the site of the lesion, then within three days there is an inflammatory reaction. After about a week, hyperpigmentation (unusual darkening of the skin) appears on the affected areas and persists for several months. Affected areas of skin can be sensitive to ultraviolet light for many years. Moisture (such as sweat) and heat can increase the skin reaction. Since the contact with the plant itself is almost painless, people who have been in contact may not be aware for several hours of the danger they are in [49-52].

According to the results of longterm research, scientists recommend to control hogweed, using methods that have proven themselves and were most effective. The first of such methods is the implementation of preventive (precautionary) measures in those areas where the occurrence of this species is most likely. For this purpose it is necessary:

- identify ways to spread the seeds and identify areas where the seeds are likely to get;

- identify the areas with the highest level of danger of invasion of hogweed;

- to teach the population to recognize (identify) hogweed;

- use modern means to monitor the spread of giant hogweed, especially to observe new populations;

- to carry out measures for destruction in those cases when preventive measures are insufficient, and further to carry out supervision over the affected territories.

Continuous (annual) intensive monitoring is recommended for areas that may be invaded by plants. This is especially important in cases where hogweed grows on the edges of agricultural fields, roadsides, arable land and meadows, near water bodies. Mowing (at least 3-5 times during the growing season) is recommended as one of the most convenient ways to control giant hogweed. Shoots should be mown from the rosette phase to the beginning of budding of plants (before flowering before tying the seeds). In this case, the hogweed will not form seeds, and the reserves of nutrients in its root system will be gradually depleted. During the growing season mowing is carried out repeatedly with an interval of 3-4 weeks after the previous mowing. This is necessary to destroy all the generative shoots of Sosnowski's hogweed, bearing inflorescences and, accordingly, flowers [49, 53].

During mowing, giant hogweeds, including single specimens, should be completely removed. Mown plants need to be destroyed. It is forbidden to stack them, as there is a danger of regeneration. If the risk of weed infestation is high and the land does not belong to agricultural land, the best preventive measure is to plant forest belts that will prevent the spread of giant hogweed. Seedlings of trees and shrubs should be large enough to be an obstacle to the spread of hogweed seeds.

Today, there are various methods for controlling giant hogweed in Europe: manual or mechanical destruction, grazing, and the use of herbicides. Recommendations for the use of a particular method are based on the methods of Integrated Weed Control Strategy (IWMS). An integrated weed control strategy offers optimal methods that take into account the peculiarities of the ecology and economy of the region [25, 49]. The choice of method depends on the size of the area in which the plants have spread, their growth density and access to thickets of hogweed. Undoubtedly, in order for the method to be truly effective, it is recommended to start the destruction of plants in early spring (at the beginning of the growing season) and not to stop for several years, until all the rhizomes and seeds in the soil are completely destroyed. One of the measures used to destroy giant hogweed is manual and mechanical methods. Manual and mechanical control methods include various technologies, such as digging and destroying roots, cutting or mowing plants, removal of 
inflorescences. Mechanical control, except for the destruction of roots, does not lead to immediate death of plants. They die only after two, three or more mowings for several seasons, after depletion of nutrients in the rhizome. Plowing helps to control the degree of infestation of giant hogweeds on agricultural land. Deep plowing (more than $24 \mathrm{~cm}$ ) will significantly impoverish the «seed bank», which is located in the upper layer of the soil. According to experts, the best result will be achieved if before plowing use a mechanical or chemical method of control $[15,28]$.

It is best to destroy the roots in early spring and then a second time in mid-summer. This method is considered very effective, but it requires high labor costs and is therefore recommended only in cases where it is necessary to destroy single plants or a small population (up to 200 plants) $[2,15,28,54]$. The roots are removed by pruning them to a depth of at least $10 \mathrm{~cm}$ below the point of growth below the root collar. If you cut higher, the root of the plant will remain a few «sleeping» buds in the leaf axils, which will restore growth and form seeds. To increase the effectiveness of this method in $1-2$ weeks after digging the place of vegetation of hogweed again inspected and pruned the roots that remained after the previous time. This procedure is repeated several times a season. Plants should be removed in this way before flowering. Plants that have peduncles, it is not advisable to dig, because they will still die (during this period it is necessary to cut the stalks or inflorescences) [15, 25].

Measures to control giant hogweeds include mechanical mowing, such as a hay mower. Mechanical mowing is used when large areas are affected by giant hogs. It is necessary to take into account that the plants regenerate quickly, and such mowing should be carried out at least 2-3 times during the growing season to prevent the plant from blooming and forming seeds.

One of the methods of controlling giant hogweeds is to cut the inflorescences on the plants during their flowering. To do this, a special «tool for hogweed» was invented, which has the appearance of a curved tip with teeth on a long handle for cutting stems at a safe distance from plants. In a few years of application of this method it is possible to achieve the eradication of the population with minimal labor costs. For the effectiveness of this method, the time of pruning plays a crucial role, because if you start too early (before they fully bloom), the regeneration will be very strong, and the seeds will be formed even more than usual. If you start later (when the seeds are ripening), there is a high risk that the seeds will ripen in already cut plants and clog the soil. Therefore, cut plants must be destroyed. The best time to remove the inflorescences when the extreme flowers began to bloom. However, even then there is a threat of regeneration. Therefore, in Europe, this method is considered a temporary solution $[15,28,49,54]$.

Methods of destroying giant hogweeds include the use of large areas affected by hogweeds for grazing. This method is no less effective than mowing. Although it took some time for the animals to get used to the hogweed and start consuming it regularly $[2,55]$.

Cattle grazing depends on the density of hogweed thickets and the season. In the spring, more animals were attracted for grazing (20-30 sheep per $1 \mathrm{ha})$, and in the summer their number was reduced $(5-10$ sheep per 1 ha), as the plants became weaker and their biomass decreased significantly. Cattle grazing is a cheap method that is recommended for use in large fenced areas. It is also recommended for small areas, if cattle graze in the surrounding areas, and which can be briefly transferred to the consumption of hogweed [55].

Based on the results of numerous experiments, it was found that giant borage is susceptible to treatment with herbicides with the active substance glyphosate or triclopyr. However, it should be borne in mind that triclopyr does not affect the shoots of giant hogweed and its use is appropriate only for the destruction of adult plants with large leaves [15, 49]. Glyphosate is the only herbicide used in Europe to control giant borage. However, the application of herbicides to unploughed land or near water bodies is prohibited by national law. European policy in general is aimed at reducing the amount of pesticides and protecting groundwater from possible herbicide contamination. Therefore, preference is given to the use of non-chemical methods of control of giant hogweed. In the case of herbicides, it is recommended to apply them in early spring, when the plants are $20-50 \mathrm{~cm}$ tall and can reach the center of the affected area.

Spraying should be repeated in late May to destroy those plants that survived after the first spraying. It is also possible to continuously spray with a preparation based on glyphosate in accordance with the manufacturer's recommendations, as an effective means of controlling giant hogweed, although during spraying there is a risk of damage to other plants in the treatment area. In areas with mixed vegetation should use special nozzles that limit the impact of drugs on other plants. It is advisable to spray in dry and warm weather.

In Belarus, spraying of plants was carried out according to the scheme: the first - from the beginning of regrowth of Sosnowski's hogweed (late May - early June); the second - before flowering (mid-August) (table).

To control Sosnowski's hogweed, it is recommended to use systemic herbicides based on the active substances glyphosate, sulfometuronmethyl, imazapyr or their tank compositions. The best time to spray is to start regrowth of borage plants and always before flowering. It should be noted that spraying plants with herbicides at the beginning of seed maturation is a less effective measure. When spraying, make sure that the working solution falls on the leaf surface and flows down the shoots into the leaf rosette, it is recommended to abundantly moisten the generative stem and inflorescences (umbrellas, if they are developed before processing).

According to both European and domestic studies, the fastest results are obtained by the use of the active substance glyphosate (N-(phosphonomethyl)-glycine, $\left.\mathrm{C}_{3} \mathrm{H}_{8} \mathrm{NO}_{5} \mathrm{P}\right)$ in the form of ammonium, isopropylamine and potassium salts $[36,38]$. In Belarus, for the control of Sosnowski hogweed registered herbicide Buran Super, v.r. 550 g/1 glyphosate acid in the form of potassium salt $663 \mathrm{~g} / 1$ [56] (table).

Also in Belarus, where Sosnowski's hogweed is most common among giant hawthorn species and occupies almost 90\% [57], Tersan herbicides containing the active substance sulfometuron-methyl, $750 \mathrm{~g} / \mathrm{kg}$, with a consumption rate of 0.05 to 0 are used to control it $35 \mathrm{~kg} / \mathrm{ha}$, Grader with the content of the active sub- 
stance imazapir $250 \mathrm{~g} / 1$, with a consumption rate of $2.0-2.51 / \mathrm{ha}$, and also promising is Magnum with the content of the active substance metsulfuron-methyl $600 \mathrm{~g} / \mathrm{ha}$, with a consumption rate $0.01-0.02 \mathrm{~kg} / \mathrm{ha}$.

In Latvia, Ariane herbicide (fluroxypyr, $86 \mathrm{~g} / 1+$ clopyralid, $23 \mathrm{~g} / 1$ + MCPA, $415 \mathrm{~g} / 1$ ) is used to destroy Sosnowski's hogweed, with a consumption rate of $2.75 \mathrm{l} / \mathrm{ha}$ in the first decade of June., separately or together with herbicides derived from glyphosate [12].

In Ukraine, it is recommended to use Roundup with a consumption rate of $6.0 \mathrm{l} / \mathrm{ha}$, or its analogues with a consumption rate of $6-81 /$ ha for plant heights of $30-50 \mathrm{~cm}$ (end of April - first half of May) to control Sosnowski's hogweed. At the same time, the main method in the country is double mowing by heavy machinery during flowering of the main inflorescence and again - as it regenerates $[53,58]$.

\section{CONCLUSIONS}

International agreements and programs aimed at addressing invasion are based on Article $8 \mathrm{Ph}$ of the Convention on Biological Diversity (1995), which states: «Each Party to the Convention shall, as far as possible and appropriate, prevent the introduction, control and destruction of alien species that threaten ecosystems, habitats or species».

Currently, there are various methods to control giant hogweeds: manual or mechanical destruction, grazing, use of herbicides. Recommendations for using this or that method are based on IWMS, Integrated Weed Control Strategy. IWMS proposes to choose the best method that should take into account the peculiarities of the environment and the economy of the region. The choice of method depends on the size of the area in which the plants have spread, their growth $d$

ensity and access to thickets of hogweed. In order for the method to be truly effective, it is recommended to start the destruction of plants in early spring (beginning of the growing season) and not to stop for several years until all the rhizomes and seeds in the soil have been completely destroyed.

Manual and mechanical control methods include various technologies, such as digging and destruction of rhizomes, cutting or mowing plants, removal of inflorescences. Mechanical control, except for the destruction of rhizomes, does not lead to immediate plant death. They die only after two, three or more mowings for several years, when the nutrient reserves in the rhizomes are depleted. Plowing helps to control the degree of littering by giant hogweeds of agricultural land. Deep plowing (more than $24 \mathrm{~cm}$ ) significantly impoverishes the «seed bank», which is located in the upper layer of the soil. The best results will be achieved if mechanical or chemical control methods are applied before plowing.

A clear understanding of the mechanism of reproduction of giant hogweeds is the key to successful control of invasive weeds.

Preparation recommended for the control of Sosnowski's hogweed

\begin{tabular}{|c|c|c|}
\hline Preparation & $\begin{array}{l}\text { Consumption rate, } \\
\text { I/ha, kg/ha }\end{array}$ & Processing method \\
\hline $\begin{array}{l}\text { Roundup, LCD } \\
\text { (glyphosate potassium salt, } 551 \mathrm{~g} / \mathrm{l} \text { ) }\end{array}$ & $3-6$ & \multirow{3}{*}{$\begin{array}{l}\text { Spraying vegetative plants } \\
\text { in May - September }\end{array}$} \\
\hline $\begin{array}{l}\text { Uragan Forte } 500 \mathrm{SL}, \mathrm{LCD} \\
\text { (glyphosate in the form of acid, } 500 \mathrm{~g} / \mathrm{l} \text { ) }\end{array}$ & $1.5-3.0$ & \\
\hline $\begin{array}{l}\text { Tornado, LCD } \\
\text { (isopropylamine salt of glyphosate } 486 \mathrm{~g} / \mathrm{l} \text {, in } \\
\text { acid equivalent }-360 \mathrm{~g} / \mathrm{l} \text { ) }\end{array}$ & 5.0 & \\
\hline $\begin{array}{l}\text { Ballerina, SE } \\
\text { (2-ethylhexyl ester of } \\
\text { 2,4-dichlorophenoxyacetic acid, } 615.0 \mathrm{~g} / \mathrm{l}+ \\
\text { florasulam, } 7.4 \mathrm{~g} / \mathrm{l} \text { ) }\end{array}$ & $2.0-4.0$ & $\begin{array}{l}\text { One-time spraying } \\
\text { of vegetative plants } \\
\text { in May - June }\end{array}$ \\
\hline $\begin{array}{l}\text { Buran super, v.r. } \\
\text { (glyphosate acid } 550 \mathrm{~g} / \mathrm{l} \text { in the form of } \\
\text { potassium salt } 663 \mathrm{~g} / \mathrm{l} \text { ) }\end{array}$ & 5.0 & \multirow{4}{*}{$\begin{array}{l}\text { Spraying vegetative plants } \\
\text { in May - September }\end{array}$} \\
\hline Groza ultra, RK BP, (glyphosate, 550 g/l) & 5.0 & \\
\hline $\begin{array}{l}\text { Grader, GHG } \\
\text { (water-glycol solution) (imazapyr, } 250 \text { g/l) }\end{array}$ & $2.0-2.5$ & \\
\hline Tersan, VG, sulfometuron-methyl, $750 \mathrm{~g} / \mathrm{kg}$ & 0.35 & \\
\hline
\end{tabular}

Glyphosate is the only herbicide used in Europe to control hogweed. However, the use of herbicides on unploughed land or near water bodies is prohibited by national law. European policy aims to reduce the use of pesticides to protect groundwater from possible herbicide contamination. Therefore, if possible, nonchemical methods should be used to control giant hogweed.

The combination of several methods was more effective than using one of them. For example, after spraying with glyphosate in early spring, a small number of surviving plants can be cut or cut with a sickle instead of applying glyphosate a second time. In the case when the height of the plants is high and glyphosate is difficult to apply, first borage was cut, and only then the area was sprayed.

After clearing the areas from the invasion of giant hogweed, reclamation is carried out to prevent soil erosion and restore the ecosystem.

\section{REFERENS}

1. Mandenova I.P. (1950). Kavkazskie vidy roda Heracleum. [Caucasian species of the genus Heracleum]. Tbilisi: Izd-vo i tip. Akad. nauk Gruz. SSR, 104 s. (in Russian).

2. Andersen U.V. and Calov (1996). Longterm effects of sheep grazing on giant hogweed (Heracleum mantegazzianum). Hydrobiologia. Vol. 340. P. 277-284.

3. Mihaly B. (2004). Biological invasions in Hungary. Floods. Study volumes of the Office for Nature Conservation 9, Nature Builder Foundation Publishing House, Budapest, p. 408. (in Hungary).

4. Mariushkina V.Ya. (2002). Adventyzatsiia roslynnosti yak naslidok spontannoi ta tsilespriamovanoi introduktsii roslyn. [Vegetation adventitia as a consequence of spontaneous and purposeful introduction of plants]. Introduktsiia roslyn. Vyp. № 1. S. 49-60. (in Ukrainian).

5. Burda R.I. (2011). Metodyka doslidzhennia adaptyvnoi stratehii chuzhoridnykh vydiv roslyn $\mathrm{v}$ urbanizovanomu seredovyshchi: monohrafiia. [Methods of research of adaptive strategy of alien plant species in urban environment: monograph]. NAN Ukrainy, Nauk. tsentr ekomonitorynhu ta bioriznomanittia mehapolisu. Kyiv: Vipol, 111 s. (in Ukrainian).

6. Burda R.I. (2006). Tendentsii zmin riznomanitnosti fitobioty $\mathrm{v}$ silskohospodarskykh landshaftakh rivnynnoi Ukrainy. [Trends in changes in phytobiota diversity in agricultural landscapes of plain Ukraine]. Naukovyi visnyk Natsionalnoho ahrarnoho universytetu. Vyp. 93. S. 1-15. (in Ukrainian).

7. Vykhor B.I. (2014). Otsinka zahrozy vplyvu invaziinykh roslyn na rehionalno ridkisni ta vkliucheni do Chervonoi knyhy Ukrainy vydy roslyn Zakarpattia. Roslynnyi svit u Chervonii knyzi Ukrainy: vprovadzhennia Hlobalnoi stratehii zberezhennia roslyn: materialy III Mizhnar. nauk. konf. [Assessment 
of the threat of the impact of invasive plants on regionally rare and included in the Red Book of Ukraine plant species of Transcarpathia. Flor in the Red Book of Ukraine: implementation of the Global Strategy for Plant Conservation: materials III International. Science. conf.] (Lviv, 4-7 chervnia 2014 r.). S. 94-98. (in Ukrainian).

8. Kudinov M.A., Kasach A.E., Chekalinskaya I.I. et al. (1980). Introdukciya borshchevikov v Belorussii. [Introduction of hogweed in Belarus]. AN BSSR, Centr. botan. Sad - Minsk: Nauka i tekhnika. 198 s. (in Russian).

9. Protopopova V.V., Mosiakin S.L., She vera M.V. (2002). Fitoinvazii v Ukraini yak zahroza bioriznomanittiu: suchasnyi stan zavdannia na maibutnie. [Phytoinvasions in Ukraine as a threat to biodiversity: current status and challenges for the future]. Kyiv: In-t botaniky im. M.H. Kholodnoho NANU. $32 \mathrm{~s}$. (in Ukrainian)

10. Protopopova V.V. (2006). Deliberate and unintentional introduction of invasive weds: $A$ case study of the alien flora of Ukraine. Euphytica. Vol. 148. P. 17-33.

11. Berko Y.M. (1964). Borshchivnyk Mantehatstsi (Heracleum Mantegazzianum Somm. Et Lev.) v Ukrainskykh Karpatakh. [Heracleum Mantegazzianum Somm. Et Lev. In the Ukrainian Carpathians]. Ukrainskyi botanichnyi zhurnal. Vyp. № 21. S. 104-106. (in Ukrainian).

12. Vykhor B.I., Prots B.H. (2014). Dynamika poshyrennia vysokoinvaziinykh vydiv roslyn Zakarpattia ta otsinka yikh vplyvu na fitoriznomanittia. Rehionalni aspekty florystychnykh i faunistychnykh doslidzhen: Mater. persho mizhnar. nauk.-prak. konf. [Dynamics of distribution of highly invasive plant species in Transcarpathia and assessment of their impact on phytodiversity. Regional aspects of floristic and faunal research: Mater. first international. scientific-practical conf.]. (10-12 kvitnia 2014 r., m. Khotyn). Vidp. red. Skilskyi I.V.; M-vo ekolohii ta pryrodnykh resursiv Ukrainy, Nats. pryrodnyi park «Khotynskyi» ta in. Chernivtsi: DrukArt, 368 p. (in Ukrainian).

13. Mariushkina V.Ya. (2007). Invaziini roslyny: hrymasy introduktsii. [Invasive plants: grimaces of introduction]. Zakhyst $i$ karantyn roslyn. Vyp. 53. S. 484-494. (in Ukrainian).

14. Mandenova I.P. (1951). Borshchevik Heracleum L. [Hogweed - Heracleum L.]. Flora SSSR, t. 17. Moskva; L.: Nauka. S. 223-259. (in Russian).

15. Pysek P., Cock M.J.W., Nentwig W. Ravn H.P. (2007). Ecology and management of giant hohweed (Heracleum mantegazzianum) CABI, 2007. $324 \mathrm{p}$.

16. Stace C.A. (2010). New flora of the British Isles. Cambridge; New York: Cambridge University Press. 2010. P. 450.

17. Giant hogweed: 8 facts you must know about the toxic plant. URL: https://www.cbsnews.com/pictures/giant-hogweed-8-factsyou-must-know-about-the-toxic-plant/.

18. Heracleum mantegazzianum Sommier et Levier (Apiaceae) na Chernihivskomu Polissi. (2003). [Heracleum mantegazzianum Sommier et Levier (Apiaceae) at Chernigivskyi Polissi]. Ukr. botanichnyi zhurnal. T. 60. № 5 . S. 561-566. (in Ukrainian).

19. Moravcova L. (2007). Seed Ecology of Heracleum mantegazzianum and H. sosnowskyi,
Two Invasive Species with Different Distributions in Europe. Ecology and Management of Giant Hogweed (Heracleum mantegazzianum). Ch. 10. Pub Date: January 2007. P. 157-169.

20. Walusiak E. (2005). Heracleum sosnowskyi Manden. and Heracleum mantegazzianum Sommier and Levier in the area of Sub Tatra Trough (Southern Poland). 8th International Conference on the Ecology and Management of Alien Plants Invasions, University of Silesia, Katowice. Abstracts book. - Uniw. Ślaski, Katowice. P. 91. (in Poland).

21. Badowski M. (2014). Badania nad skutecznością zwalczania barszczu Sosnowskiego. URL: https://www.farmer.pl/ produkcja-roslinna/ochrona-roslin/badanianad-skutecznoscia-zwalczania-barszczu-sosnowskiego,49445.html. (in Poland).

22. Bogdanov V.L. (2010). Biologicheskoe zagryaznenie territorii ekologicheski opasnym rasteniem borshchevikom Sosnovskogo. Fundamental'nye mediko-biologicheskie nauki i prakticheskoe zdravoohranenie: sb. nauch. trudov 1-j Mezhdunarodnoj telekonferencii. [Biological pollution of the territory with an ecologically dangerous plant of Sosnovsky's hogweed. Fundamental biomedical sciences and practical health care: collection of articles. scientific. proceedings of the 1st International Teleconference]. (Tomsk, 20 yanvarya $-20 \mathrm{fe}$ vralya, 2010). Tomsk: SibGMU. S. 27-29. (in Russian).

23. Shumova E.M. (1972). Morfologiya glavnogo pobega borshchevika Mantegacci (Heracleum mantegazzianum Somm. et Lev.) $\mathrm{v}$ yuvenil'nyj period. [Morphology of the main shoot of the Mantegazzi hogweed (Heracleum mantegazzianum Somm. Et Lev.) In the juvenile period.]. Doklady TSKHA. Vyp.180, ch. 2. S. 235-242. (in Russian).

24. Shtejnberg M.A. (1958). Fotodermatozy. [Photodermatosis.]. Moskva: Medgiz, 1958. 131 s. (in Russian).

25. Laman N.A., Prohorov V.N., Maslovskij O.M. (2009). Gigantskie borshcheviki opasnye invazivnye vidy dlya prirodnyh kompleksov i naseleniya Belarusi. [Giant hogweed are dangerous invasive species for natural complexes and the population of Belarus]. In-t eksperiment. botaniki im. V.F. Kuprevicha. NAN Belarusi. 40 s. (in Russian).

26. Tutin T.G., Moore D.M., Halliday G. and Beadle. (1981). Flora Europaea. Rosaceae to Umbelliferae. Cambridge University. Vol. 2. Press. $470 \mathrm{p}$.

27. Shuvar I.A., Hudz V.P., Shuvar A.I. (Shuvar I.A. Ed.). (2013). Osoblyvo nebezpechni roslyny Ukrainy: navch. posibnyk. [Particularly dangerous plants of Ukraine: textbook. manual. For order. I.A. Shuvar]. Kyiv: «Tsentr uchbovoi literatury». 193 s. (in Ukrainian).

28. Dal'ke N. V., Chadin I. F. (2008). Metodicheskie rekomendacii po bor'be s nekontroliruemym rasprostraneniem borshchevika Sosnovskogo. [Methodological recommendations for combating the uncontrolled spread of Sosnovsky's hogweed]. Syktyvkar, 28 s. (in Russian).

29. Simpson M., Prots B., Vykhor B. (2011). Modeling of the invasive plant distribution: case study of Sosnowski's hogweed Heracleum sosnowskyi Manden. in the Ukrainian Carpathian Mts. Bulletin of Chernivtsi University. Biol. System. T. 3., Vip. 1. S. 80-89. (in Ukrainian).
30. Tahtadzhyan A.L. (1981). Cvetkovye rasteniya. [Flowering plants.]. Moscov: Prosveshchenie, 1981. S. 302-309. (in Russian).

31. Lambdon P., Pyšek P., Arianousou M. et al. (2008). Alien flora of Europe: species diversity, temporal trends, geographical patterns and research Needs. Preslia. Vol. 80. P. 101-149.

32. Laivins M., Gavrilova G. (2003). Heracleum sosnowskyi in Latvia: sociology, ecology and distribution. Latvijas Vegetacija. Vol. № 7. P. 45-65. (in Latvia).

33. Giant Hogweed (Heracleum mantegazzianum). Best Management Practices in Ontario. URL: https://www.ontarioinvasiveplants ca/wp-content/uploads/2020/10/GiantHogweed_BMP.pdf

34. Kabuce N., Priede N. (2010). Nobanis. Invasive Alien Species Fact Sheet - Heracleum sosnowskyi. From Online Database of the North European and Baltic Network on Invasive Alien Species. URL: https://www.nobanis.org/globalassets/speciesinfo/h/heracleum-sosnowskyi/ heracleum-sosnowskyi.pdf

35. Chujko E. V. (2012). Ocenka ekspansii Heracleum sosnowskyi Manden. na territorii Belarusi. Aktual'ni problemi botaniki ta ekologii: Mater. mizhnar. konf. mol. vchenih. [Evaluation of the expansion of Heracleum sosnowskyi Manden. on the territory of Belarus. Actual problems of botany and ecology: Mater. international conf. mol. scientists]. (19-23 veresnya 2012 r., m. Uzhgorod). Uzhgorod: Vidavnictvo FOP Breza A.E. S. 173-174. (in Russian).

36. Fintha I.A. (2005). Heracleum Sosnovskyi Manden. a new adventitious species in the Hungarian flora. Botanical Bulletins. Vol. 92 (1-2). P. 167-171. (in Hungary).

37. Balazh B.O. (2012). Do pytannia invazii Heracleum sosnowskyi Manden. na terytorii Zakarpattia. [On the question of invasion of Heracleum sosnowskyi Manden. on the territory of Transcarpathia]. Aktualni problemy botaniky ta ekolohii: Mater. mizhnar. konf. mol. uchenykh. (19-23 veresnia 2012 r., Uzhhorod) [Actual problems of botany and ecology: Mater. international conf. mol. scientists]. Uzhhorod: Vydavnytstvo FOP Breza A.E. S. 72-73. (in Ukrainian).

38. Vykhor B.I., Prots B.H. (2012). Borshchivnyk Sosnovskoho (Heracleum sosnowskyi Manden.) na Zakarpatti: ekolohiia, poshyrennia ta vplyv na dovkillia. [Sosnowski's heracleum (Heracleum sosnowskyi Manden.) In Transcarpathia: ecology, distribution and impact on the environment]. Biolohichni studii. Vyp. 6 № 3. S. 185-196. (in Ukrainian).

39. Dunaeva E.A. (2010). Vliyanie Borshchevika Sosnovskogo (Heracleum sosnowskyi) na bioraznoobrazie rastitel'nogo soobshchestva: II Obshcherossijskaya studencheskaya elektronnaya nauch. konf. «Studencheskij nauchnyj forum». [Influence of the Sosnowsky hogweed (Heracleum sosnowskyi) on the biodiversity of the plant community: II All-Russian student electronic scientific. conf. «Student Scientific Forum»]. (15-20 fevralya 2010 g.) URL: http:// www.rae.ru/forum2010/10/274. (in Russian).

40. Evangelista, P.H., Sunil, K., Stohlgren, T.J. et al. (2008). Modeling invasion for a habitat generalist and a specialist plant species. Diversity and Distribution 14. P. 808-817.

41. Konechnaya G.Yu., Krupkina L.I. (2011). Dinamika vidovogo sostava soob- 
shchestv s borshchevikom Sosnovskogo v nacional'nom parke «Sebezhskij». Sornye rasteniya $v$ izmenyayushchemsya mire: aktual'nye voprosy izucheniya raznoobraziya, proiskhozhdeniya, evolyucii: Mater. I Mezhdunar. nauch. konf. [Dynamics of the species composition of communities with Sosnovsky hogweed in the Sebezhsky national park. Weeds in a Changing World: Topical Issues of Studying Diversity, Origin, Evolution: Mater. I Int. scientific. conf.] (6-8 dekabrya 2011 g., Sankt-Peterburg). SPb. VIR, S. 125-132. (in Russian).

42. Vykhor B.I., Prots B.H. (2009). Otsinka vplyvu vysokoinvaziinykh vydiv roslyn na dovkillia. Molod i postup biolohii: Zbirnyk tez V Mizhnar. nauk. konf. studentiv ta aspirantiv. [Assessment of the impact of highly invasive plant species on the environment. Youth and the progress of biology: Collection of abstracts $\mathrm{V}$ International. Science. conf. students and graduate students]. (12-15 travnia 2009 r., $\mathrm{m}$. Lviv): $U 2 t$. T. 1. Lviv. 296 s. (in Ukrainian).

43. Oitsius L.V. (2017). Adventyvni vydy flory u skladi lisovykh ta luchnykh uhrupovan Volynskoho Polissia. Materialy konferentsii VI Vseukrainskoho zizdu ekolohiv. [Adventive species of flora in the forest and meadow groups of Volyn Polissya. Mater. conf. of the VI All-Ukrainian Congress of Ecologists.]. 21-22 veresnia 2017 r. VNTU. S. 139. (in Ukrainian).

44. Soloveva A.I., Dolgih Yu.I., Osipova E.S. et al. (2011). Vyyavlenie polimorfizma borshchevika Sosnovskogo (Heracleum Sosnowskyi) s pomoshch'yu rapd, issr, remap. [Revealing polymorphism of Sosnowsky's hogweed (Heracleum Sosnowskyi) using rapd, issr, remap.] Kyiv: Biologiya rastenij i biotekhnologiya: $\mathrm{Sb}$. tezisov Pervoj konf. molodyh uchenyh (s mezh dunarodnym uchastiem) (5-7 oktyabrya 2011, g. Belaya Cerkov', Ukraina). S. 64. (in Russian)

45. Pesnya D. S., Serov D. A., Vakorin S. A. et al. (2011). Issledovanie toksicheskogo, mitozmodificiruyushchego i mutagennogo dejstviya borshchevika Sosnovskogo. [Investigation of the toxic, mitosis-modifying and mutagenic effects of Sosnovsky's hogweed.]. Yaroslavski pedagogicheskij vestnik (Estestvennye nauki). V. № 4. Tom III. S. 93-98. (in Russian).

46. Termena B.K., Stefanyk V.I., Serpokrylova L. S. et al. (1992). Konspekt flory Pivnichnoi Bukovyny (sudynni roslyny). [Summary of the flora of Northern Bukovina (vascular plants)] Chernivtsi, 1992. 227 s. (in Ukrainian).

47. Mosiakin A.S. (2012). Suchasni metody biolohichnoho kontroliu (biolohichnoho rehuliuvannia) aktyvnosti invaziinykh roslyn: pryklady y perspektyvy zastosuvannia. [Modern methods of biological control (biologica regulation) of invasive plant activity: examples and prospects of application]. Naukovi osnovy zberezhennia biotychnoi riznomanitnosti. T. 3 . № 1. S. 93-109. (in Ukrainian).

48. Heracleum mantegazzianum, $H$. sosnowskyi and H. persicum (2009). Bull. OEPP. Organisation Europ. et mediterraneene pour la protection des plantes. Oxford, 2009. Vol. 39. P. 465-470.

49. Nielsen C., Ravn H.P., Nentwig W., Wade M. (Eds.). (2005). The Giant Hogweed Best Practice Manual. Guidelines for the management and control of an invasive weed in Europe. Forest \& Landscape Denmark, Hoersholm, $44 \mathrm{pp}$

50. Krejer V.G., Sokolov V.S. (1965). Izuche- nie furokumarinov borshchevika Sosnovskogo (Heracleum sosnowskyi Manden). [Study of furocoumarins of Sosnowsky hogweed (Heracleum sosnowskyi Manden.)]. Trudy BIN AN SSSR. Ser. V. 1965. Vyp. 12. S. 61-65. (in Russian).

51. Gusev N.F., Neiereshina O.N., Petrova G.V., Filippova A.V. (2011). Lekarstvennye i yadovitye rasteniya kak faktor biologicheskogo riska: Monografiya. [Medicinal and poisonous plants as a biological risk factor. Monograph]. Orenburg: Izdatel'skij centr OGAU. 400 s. (in Russian).

52. Pavliuchok-Hoherchak O.V. (2011). Vyvchennia fotodynamichnoi aktyvnosti rechovyn, yaki mistiatsia v roslynakh rodu Heracleum L. [Study of photodynamic activity of substances contained in plants of the genus Heracleum L.]. Aktualni problemy botaniky ta ekolohii: Materialy mizhnarodnoi konferentsii molodykh uchenykh. [Actual problems of botany and ecology: Mater. international conf. mol. scientists]. (9-13 serpnia $2011 \mathrm{r}$.), m. Berezne, Rivnenska obl., Ukraina. K.: TOV «Veles». S. 191. (in Ukrainian).

53. Vykhor B.I., Prots B.H. (2015). Kontrol chyselnosti populiatsii borshchivnyka Sosnovskoho - Heracleum Sosnowskyi Manden. [Control of the number of populations of Sosnowski's hogweed - Heracleum Sosnowskyi Manden]. Molod i postup biolohii: Zbirnyk tez XI Mizhnar. naukovoi konf. studentiv i aspirantiv. [Youth and the progress of biology: Collection of abstracts XI International. scientific conference students and graduate students]. (20-23 kvitnia 2015 r., m. Lviv). Lviv: SPOLOM, 2015. 556 s. (in Ukrainian).

54. Laman N.A., Prohorov V.N. et al. (Parfenov V.I. ed.). (2012). Vliyanie razlichnyh sposobov udaleniya rozetki list'ev na posleduyushchij rost i razvitie rastenij borshchevika Cosnovskogo (Heracleum Sosnowskyi Manden.). [Influence of different ways of removing the rosette of leaves on the subsequent growth and development of plants of Sosnowskyi hogweed (Heracleum Sosnowskyi Manden.)]. Problemy sohraneniya biologicheskogo raznoobraziya $i$ ispol'zovaniya biologicheskih resursov: Mater. II mezhdunar. nauch.-prak. konf. Sb. nauch. Rabot. [Problems of biodiversity conservation and use of biological resources: Mater. II int. scientific-practical conf. Sat. scientific. Works]. Minsk: Minsktipproekt. 536 s. (in Russian)

55. Lucey J. (1994). Records of the giant hogweed, Heracleum mantegazzianum Sommier and Levier, along southern Irish rivers and streams with a revised distribution map for the region. Bulletin of the Irish Biogeographical Society. Vol. 17 (1). P. 2-6.

56. Yakimovich E.A., Ivashkevich A.A. (2011). Perspektivy ispol'zovaniya gerbicidov sploshnogo dejstviya $i$ ih bakovyh smesej dlya bor'by s borshchevikom Sosnovskogo. [Prospects for the use of continuous herbicides and their tank mixtures to combat Sosnovsky's hogweed]. Sb. nauch. tr. Zashchita rastenij RUP «Institut zashchity rastenij». Nesvizh: Nesvizhskaya ukrupn. tipografiya, 2011. Vyp. 35. $336 \mathrm{~s}$. (in Russian)

57. Motyl' M.M., Galynskaya N.A., Sandrozd YU.I., Putyrskaya I.N. (2012) Invaziya borshchevika Sosnovskogo i perspektivy ee ustraneniya v Belarusi. Introdukciya, sohranenie $\mathrm{i}$ ispol'zovanie biologicheskogo raznoobraziya mirovoj flory. [Infestation of Sosnovsky hogweed and prospects for its elimination in Belarus. Introduction, conservation and use of biological diversity of the world flora]. Mater. Mezhdunar. konf., posvyashchennoj 80-letiyu Central'nogo botanicheskogo sada NAN Belarusi. [Mater. Int. Conf., dedicated to the 80th anniversary of the Central Botanical Garden of the National Academy of Sciences of Belarus]. (19-22 iyunya 2012 g., Minsk). Nac. akad. nauk Belarusi, Centr. bot. sad. Minsk. 492 s. (in Russian)

58. Yakimovich E. A., Ivashkevich A. A., Soroka S. V. (2011). Himicheskij metod v bor'be s borshchevikom Sosnovskogo. [Chemical method in the fight against Sosnovsky's hogweed]. Nauka i innovacii. Minsk: Belorusskaya nauka. Vyp. № 3. S. 15-16. (in Russian).

\section{Сторчоус I.M.}

Інститут захисту рослин НАAН вул. Васильківська, 33, м. Київ, Україна, 03022, e-mail: igor_storchous@ukr.net

\section{ІІкідливість гігантських борщівників Heracleum та методи контролю}

Мета. Аналіз та узагальнення віт чизняного $i$ зарубіжного досвіду шодо ін вазії й шкідливості гігантських борщзівни ків, у тому числі боршівника Сосновського Heracleum Sosnowskyi Mandenova для noширення науково-облрунтованої інфор мачіï про практичні методи контролю та запобігання подальшому поширенню гігантських борщівників, сприяючи збереженню біологічного різноманіття. Методи. Системно-аналітичний, абстрактнологічний, емпіричний. Результати. Вчені встановили, шзо проникнення чужорідних видів на нові території відбувається постійно. Яскравим прикладом є ситуація з гігантськими борщівниками. Завезении в Західну Європу в XIX столітmі як декоративна рослина, бориівник Мантегаи иі нині становить реальну небезпеку для екосистем практично всіх країн Європейського континенту. Насіння лондонськой популячї боршівника перського у 1836 р. англійські садівники висіяли в північніи Норвегї, звідти він швидко поширився по всіх Скандинавських крайнах. У колишньому СРСР в повоєнні роки активно вивчали i впроваджували боршівник Сосновського, нині він набув значного почирення в природних екосистемах країн СНД та України зокрема. Висновки. Гігантські борщівники становлять велику небезпеку $i$ загрожують природним екосистем нашої країни і Заходу. Контроль боршівника Мантегаичі буде набагато складнішим i затратнішим, ніж боршівника Сосновського. 3 иієї причини необхідно першочергово здійснювати превентивні заходи щодо встановлення місиезнаходження видалення рослин дуже небезпечних інвазійних видів та інших видів з полікарпічним ичклом розвитку, а також недопущення їх широкого поширення.

гігантські борщівники; борщівник

Сосновського; інвазійні види; шкідливість; методи контролю

\section{Сторчоус И.Н.}

Институт защиты растений НААН, ул. Васильковская, 33, г. Киев, 
Украина, 03022,

e-mail:igor_storchous@ukr.net

Вред гигантских борщевиков Heracleum и методы их контроля

Цель. Анализ и обобщение отечествен ного и зарубенного опыта инвазии и вредоносности гигантских борщевиков, в том числе бориевика Сосновского Негасlеит Sosnowskyi Mandenova, для распростране ния научно-обоснованной инбормации о практических методах контроля и предотвращения дальнейшего распростране ния гигантских борщевиков, способствуя сохранению биологчческого разнообразия.

Методы. Системно-аналитический, аб страктно-логический, эмпирический. Результаты. По результатам исследований ученые предположили, что проникновение чужеродных видов на новые территории происходит постоянно. Однако все больше эти прочессы усиливаются под влиянием деятельности человека. Ярким примером этого является ситуация с гигантскими боршевиками. Завезенный в Западную Европу в XIX веке в качестве декоративного растения боршевик Мантегации сегодня представляет реальную опасность для экосистем практически всех стран Европейского континента. Семена тондонской популячии борщевика персидского в 18362. английскими садоводами высеяны в северной Норвегии, откуда он быстро распространился по всем Скандинавским странам. В бывшем СССР в послевоенные годы активно изучался и внедрялся борщевик Сосновского, которьй в настоящее время широко распространен в природньх экосистемах стран СНГ и Украины в частности. Выводы. По результатам исследований ученые предположили, что гигантские борщевики представляют большую опасность и угрожают естественным экосистемам нашей страны и Запада. Контроль борще вика Мантегации будет гораздо сложнее и затратнее, чем борщевика Сосновского. По этой причине крайне необходимо в первую очередь осушествлять превентивные мерь по установлению местонахождения и удатению растений очень опасньх инвазивньх и других видов с поликарпчческим изклом развития, а также не допускать их иирокого распространения.

гигантские борщевики; борщевик Сосновского; инвазивные виды; вредность; методы контроля

Received on 23.05.2021 